\title{
ANALYSIS OF PUBLIC AND INDIVIDUAL TRANSPORTATION IN CZECHIA: SPATIAL DIFFERENTIATION AND CONDITIONAL FACTORS
}

\author{
VIKTOR KVĚTOŇ, MIROSLAV MARADA \\ Department of Social Geography and Regional Development \\ Faculty of Science, Charles University \\ Albertov No. 6, 12843 Prague 2, Czech Republic \\ e-mail:kveton1@natur.cuni.cz marada@natur.cuni.cz
}

\begin{abstract}
The main aim of the article is detailed evaluation of spatial differentiation of transport opportunities, that means supply of public transport connections (bus and train), and household's equipment by cars at the municipal level. From the methodological point of view there are two main levels of observing: - the analysis of differentiation of transport opportunities through common statistical indicators characterizing the entire set ("Global Statistics"),

- using local statistics, specifically the method of spatial autocorrelation (LISA procedure).

Article content is divided into two parts. The first addresses the evaluation of the state of spatial differentiation. In the second part the text deals with effect of the supposed socio-geographic as well as geo-social factors determined spatial differentiation of transport opportunities. This analysis is done with using "global" correlation analysis (Pearson's coefficient). Some theoretical remarks about statistical distribution of indicators and summary of results conclude the article.
\end{abstract}

Key words: transport, degree and level of automobilization, evaluation, spatial and regional differentiation

\section{INTRODUCTION}

Transport services and links are traditional topics of transport-geographical researches. The importance of this research topic, of course, increased significantly after 1989, when the majority of settlements with dense public transport underwent a selective reduction in the number of connections, especially in the smallest villages. This trend, of course, prompted an increase in motorization of Czech households, which is-at least in small villages - to some extent compensation for declining access to public transport (Květoň 2006; Marada and Hudeček 2006). But it would be a mistake to 
believe that prior to 1989 small rural villages had low automobilization. The interesting point related with higher degree of automobilization of the Bohemian countryside against the Moravian one has found out already on the results of Census 1980.

Detailed evaluation of spatial differentiation of transport opportunities, that means supply of public transport connections (bus and train), and household's equipment by cars at the municipal level is the main aim of this article. From the methodological point of view there are two main levels of observing. First, the analysis of differentiation of transport opportunities through common statistical indicators characterizing the entire set ("Global Statistics") and then using local statistics, specifically the method of spatial autocorrelation (LISA procedure). Article content is divided into two parts. The first addresses the evaluation of the state of spatial differentiation. In the second part the text deals with effect of the supposed socio-geographic as well as geo-social factors determined spatial differentiation of transport opportunities. This analysis is done with using "global" correlation analysis (Pearson's coefficient). Some theoretical remarks about statistical distribution of indicators and summary of results conclude the article.

\section{ANALYSIS OF TRANSPORT INDICATOR DIFFERENTIATION BASED ON GLOBAL STATISTICS}

Initial empirical analysis is focused on the evaluation of spatial differentiation in terms of availability of public transport and household's equipment by cars (also automobilization). This evaluation was done at the municipal level (6 258 unites) and also at the micro-regional level (166 socio-geographic micro-regions), which were defined according to last census data 2001 (Hampl 2005). These micro-regions have been determined "naturally", on the basis of prevailing commuting that has a relatively high homology with the direction of public transport connections. A set of main characteristics on the transport parameters rate of variability at both levels is possible to observe one Table 1. Supply of public bus and rail transport has a high spatial variability. Standard deviation indicates the absolute level of variability is the highest in case of a bus services supply, on both observed levels. It is therefore evident that the bus service has the highest differences between municipalities and regions. By contrast, in case of level of automobilization as the relative indicator, there is a long-term reduction of differences (Květoň 2006) and therefore the resulting variability is relatively low. Due to greater sample size (6 258 municipalities) it was able to calculate the values of Moran's I criteria. Its values confirm that the rate of significant spatial clustering in the whole set of municipalities is the highest in case of automobilization, while at both public transport subsystems the values are significantly lower. In other words the rate of automoblization does not show such differences as the supply of public transport.

Despite mentioned long-term processes of reduction in the number of public transport connections, relatively high supply in the majority of microregions is evi- 
dent. These include the micro-regions in South Moravia and in part of Silesia. Potential conditional factors will be examined in detail in the following chapters, however, a significant association of public transport connections number with a population size of municipalities and their transport position has been previously confirmed in some case studies (Marada et al. 2008; Květoň at al. 2009). The type of rural settlements, which is generally more dispersed in Bohemia in contrary with Moravia, causes lower economic efficiency of provided transport services and investments in general. Conversely the best served municipalities are typically found in the hinterland of large cities, e.g. countryside touched by sub-urbanization process.

The difference between Bohemia (with the exception of Ore mountains and North-Bohemian basin regions) and the Moravia-Silesia area is the main feature in case of the households' equipment by cars (automobilization), as well. Of course, high automoblization is in larger cities, where car ownership is a manifestation of greater wealth of the urban population and partly of a different lifestyle. Automoblization of rural municipalities is conditioned also by the need of accessibility (higher age of cars in rural regions against the more urbanized districts was identified-Marada Hudeček 2005). Increased automoblization is particularly evident in small municipalities in so-called inner peripheries (i.e. provincial borders in Bohemia and Bohemian-Moravian frontier). Based on the above facts-concerning the regional differentiation in terms of public transport and automobilization-we can emphasise some kind of "complementarity" between the public and private (individual) transport. Similar relation is mentioned also by Moseley et al. (1977) in case of Norfolk, East Anglia and North Walsham regions in Great Britain, by Nutley (1998) or Knowles at al. (2008).

Table 1. Basic differentiation of transport indicators at municipality and socio-geographic microregion level

\begin{tabular}{|c|c|c|c|c|c|c|c|c|c|}
\hline & \multicolumn{4}{|c|}{ Municipal level } & \multicolumn{5}{|c|}{ Micro-regional level } \\
\hline & 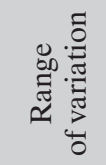 & 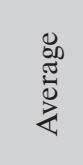 & 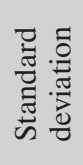 & 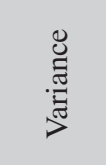 & 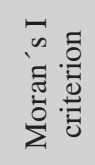 & 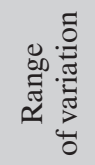 & \begin{tabular}{l}
8 \\
\multirow{0}{0}{} \\
0 \\
2 \\
2
\end{tabular} & 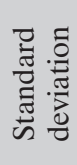 & 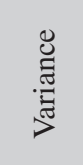 \\
\hline Automobilization & 72.73 & 59.92 & 8.67 & 75.15 & 0.3328 & 24.42 & 58.31 & 5.60 & 31.41 \\
\hline Bus supply & 1395.00 & 32.63 & 43.32 & 1876.51 & 0.1408 & 120.71 & 35.59 & 18.97 & 359.82 \\
\hline Train supply & 500.00 & 8.64 & 20.94 & 438.35 & 0.0482 & 80.70 & 10.46 & 8.67 & 75.20 \\
\hline Bus share & 100.00 & 83.69 & 28.59 & 817.40 & 0.1035 & 61.62 & 82.98 & 9.92 & 98.32 \\
\hline Train share & 100.00 & 12.78 & 23.81 & 566.89 & 0.0983 & 51.76 & 14.08 & 8.15 & 66.43 \\
\hline
\end{tabular}

Source: Census 2001 (CSO), electronic time-table IDOS (CHAPS Brno).

Notice: Automobilization $=$ share of households equipped by one and more cars; Bus supply = number of bus connections leaving the municipality in "common Wednesday" (4th April 2001, i.e. census year); Train supply = similarly to Bus supply, number of fast-trains was weighted by 3 ; Bus share $=$ share of bus connections on whole weighted number of public transport connections (bus + train) in municipality. Similarly Train share. 


\section{ANALYSIS OF TRANSPORT INDICATORS DIFFERENTIATION BASED ON LOCAL AUTOCORRELATION (LISA)}

Another view on spatial differentiation of transport indicators could be provided with help of spatial autocorrelation statistics, namely using the LISA method. LISA was used for analysing the public transport connections as a whole (bus plus train connections) and for the level of automobilization. These two indicators show a different character of spatial autocorrelation, as we supposed, and we can identify areas (clusters) of below-average and above-average values, concerning their proximity. In accordance with the previously mentioned findings, categorization of municipalities by LISA analysis (Figure 1 and 2) shows clusters of municipalities with high supply of public transport mainly in Brno region, parts of east and central Moravia and mainly in wider Ostrava region. At the same time we can see a relatively large clusters with above-average supply of public transport in the hinterland of Prague (the region Prague-East and Prague-West and Kladno), in the Most region in north-west Bohemia and around Karlovy Vary in west Bohemia. In a similar way we can identify areas with low supply of public transport, which are particularly in the area of Central and South Bohemia and also in the Bohemian-Moravian Highlands region. A location of such clusters at the administrative borders of these regions/self-administrative provinces is characteristic feature (these are the so-called inner peripheries of Czechia). The main benefit of LISA analysis is identification of the areas of similar character in terms of public transport, in which future qualitative research should be carried out with aim to find out the local context and factors. It is challenging question for future research whether the settlements units in the border regions also communicate with centres in the neighbouring region and whether it is consistent with transport links. Or vice versa if the administrative boundaries of regions are not 'barrier' for transport contacts, which is the transport policy of "artificially" intensified.

LISA analysis showed a much higher degree of spatial autocorrelation in case of automobilization (corresponding to higher value of Moran's I criteria=lower differentiation, it is possible to identify large clusters of municipalities with similar car equipment). Some works (e.g. Květoň 2006; Květoň and Marada 2008) searching automobilization at the higher level of districts found out certain southwest-northeast gradient. Despite the fact that in case of municipality level analysis the gradient is not quite evident, we can confirm wide regional inequalities. In particular, the industrial region in Nort-west Bohemia "undermines" traditional distribution, which is at the district base evident. "Macro-differentiation"-comparison of Bohemia and Moravia-is near opposite than in case of public transport supply. 


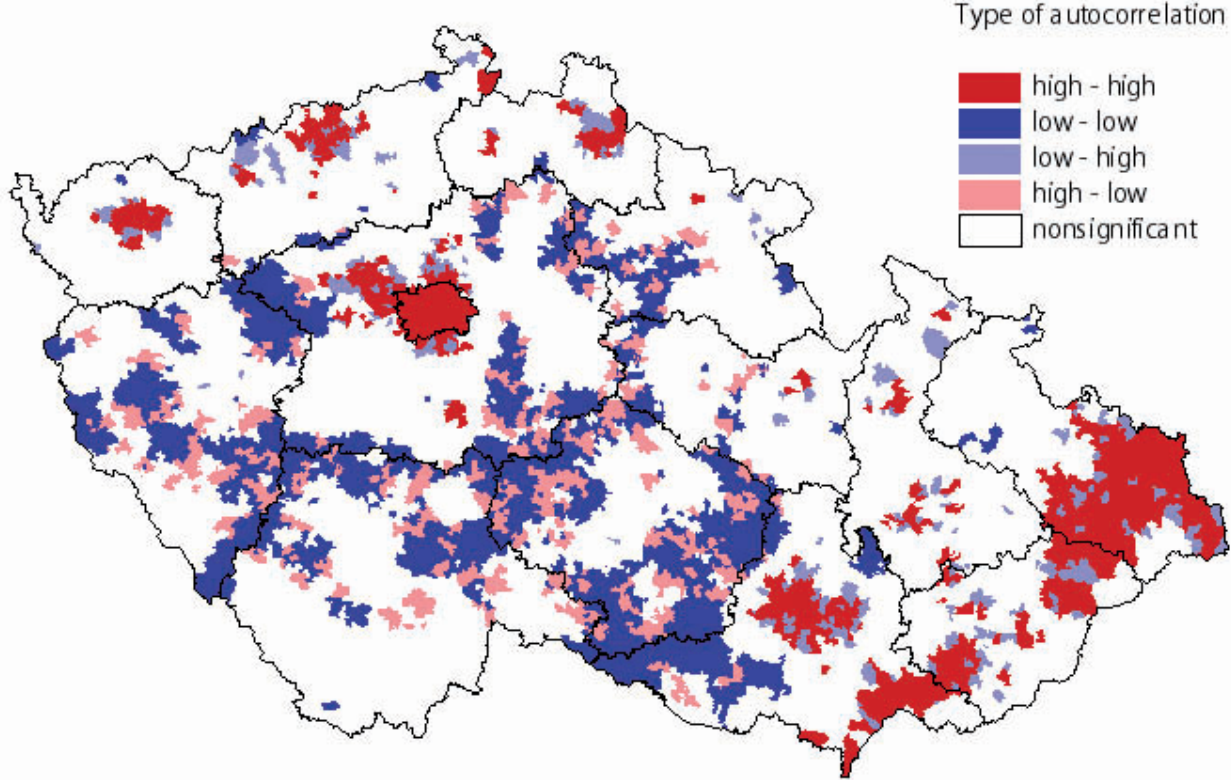

Figure 1. Public bus and railway connections-categorization of municipalities based on spatial autocorrelation (LISA procedure)

Source: Census 2001 (Czech Statistical office), programme GeoDa 0.9.5-i.

Note: all values are statistically significant at the $5 \%$ level.

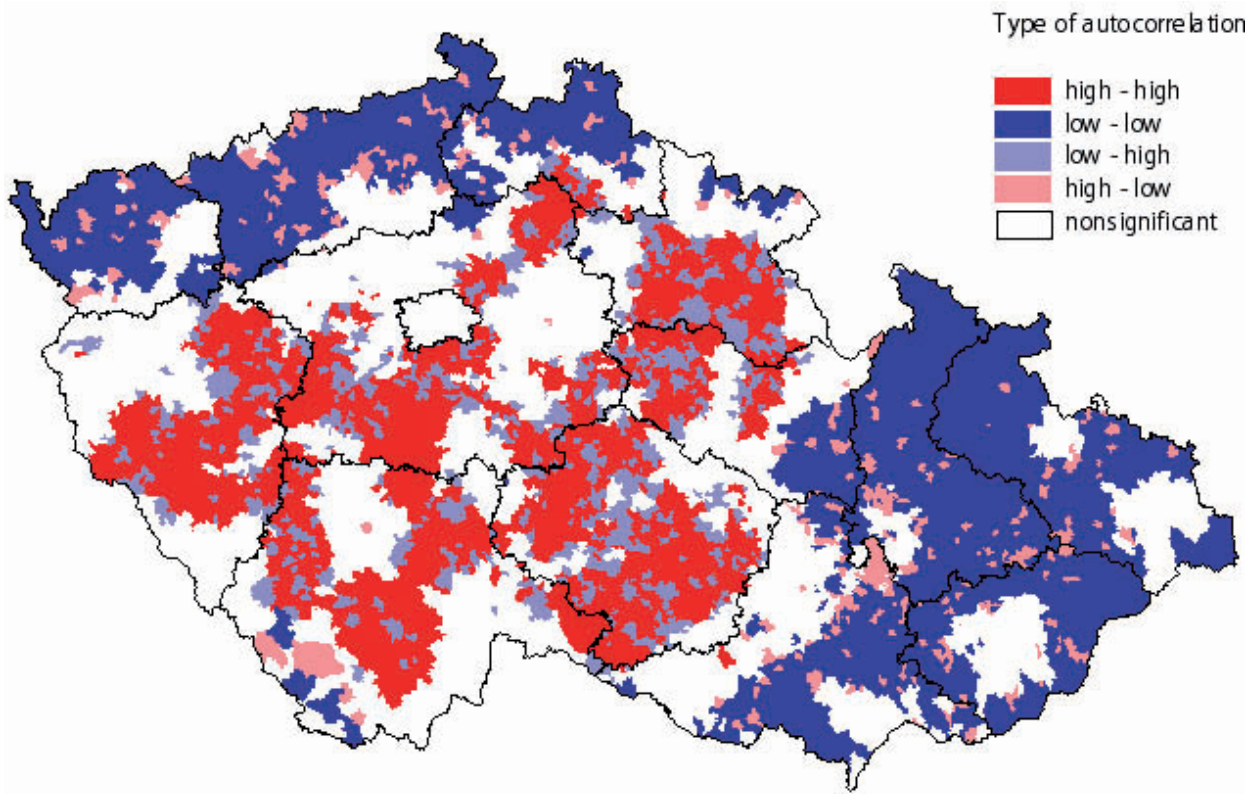

Figure 2. Automobilization-categorization of municipalities based on spatial autocorrelation (LISA procedure)

Source: Census 2001 (Czech Statistical Office), programme GeoDa 0.9.5-i. Note: all values are statistically significant at the $5 \%$ level. 


\section{CONDITIONAL FACTORS OF TRANSPORT POSSIBILITIES IN CZECHIA}

The next chapter is focused on finding and basic description of main conditional factors of transport differentiation in Czechia. Generally it is possible to divided factors into two main groups-objective factors (number of inhabitants in the settlement unit, geographical position, density of population etc.) and subjective factors (related especially to choice of the transportation). At the same time it is possible to results from the system of factors, mechanism and processes presented by Hampl, Blažek and Žižalová (2008), who distinguish geographical, socio-economic and sociocultural factors. In reality there are also very significant "cross-structure" factorsinstitutional ones, because they considerably influences a transport sector (particularly bus and train planning and subsidised services). Such scheme is illustrated in the Figure 3. Natural conditions, settlement hierarchy and geographical position (as well as transport position) belong among substantial geographical factors. In case of socio-economic factors we can suppose significant influence of unemployment, average wages, but we can consider also the structure and size of firms. For example high number of commuters to large industrial companies might have favourably influence the public transport planning. Average wages show the level of living standard and there level can associate with means of transport used. Last but not least it is necessary to emphasize socio-cultural factors, where we can point out some tradition of using public or individual (automobile) transport, conventions of passengers and their decision making in context of public transport prices, necessity of changes during the journey or standard of travelling etc. During the transformation period the role of institutional factors has been increased, which include many "soft" and hardly quantifiable factors. These factors are connected with decision making of central as well as regional governments. They have an influence on financing and planning the extent, directions and frequency of public transport services. We can include also unfinished transformation of railway transportation, splitting of competences in public transport planning among different institutions, law setting etc.

Correlation relationships among transport supply indicators and selected presumable conditional factors are presented in the Table 2. From the comparison of correlation relationships it is possible to differentiate relationships of indicators at the municipality level as well as at the microregional level. The main results are shortly commented in next points:

- Significant dependence between the level of public bus and rail transport with a population size of municipalities were expected and it confirmed the general volume of direct relevance to public transport and population. Automobilization rate in case of the municipal level shows rather independence, but at micro-regional level it is already a significant negative dependence on the population size of municipalities. This indicates a certain randomness in the rate of automoblization in municipalities, which is, at this level, strongly influenced by subjective factors. 


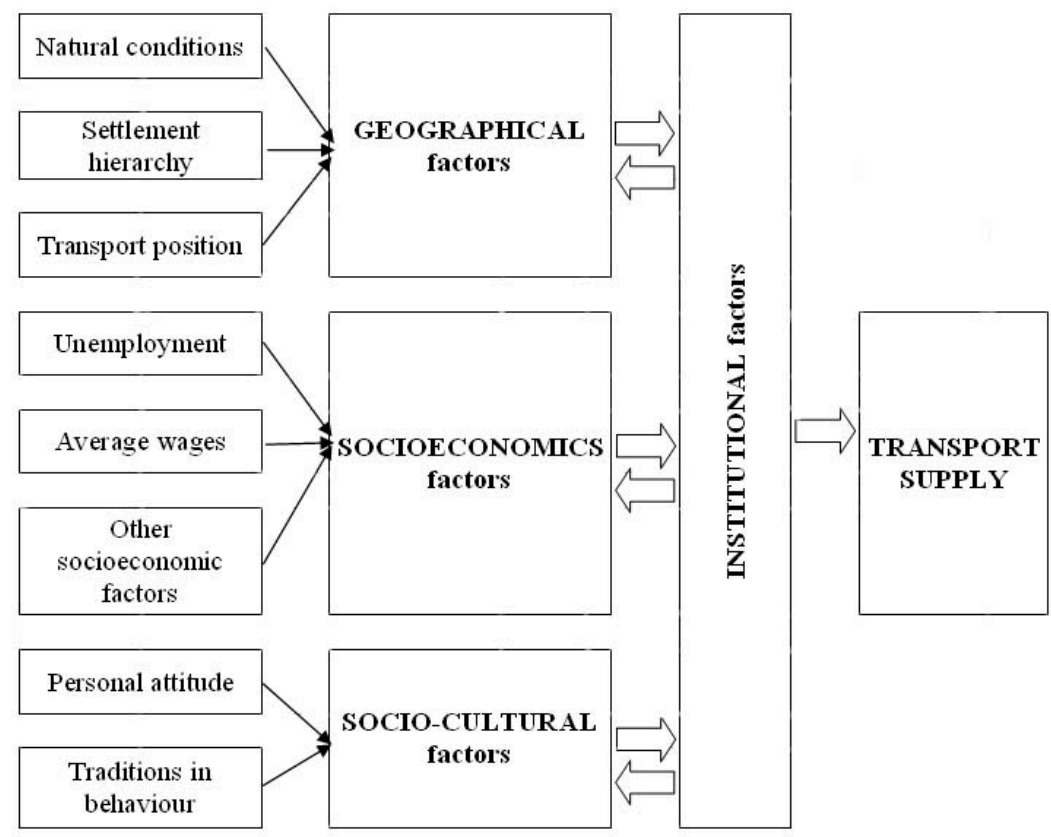

Figure 3. Main scheme of conditional factors influencing transport supply Source: amended after Hampl et al. (2008).

- Relationship among segments of transport supply (bus, trains, cars) are higher in the case of municipalities, which is caused not only by a larger number of units, but also by the fact that micro-regional data are generalized (they show average values of indicators). We can also pointed out the complementarity of transport modes, particularly at municipal level.

- Socio-economic factors have a demonstrable association with the transport possibilities of the population. The evaluation of the relationship of unemployment and household's equipment by cars (automobilization) shows quite clearly a negative relationship (in the case of unemployment the closest dependence), while the supply of public transport is rather neutral. It is therefore clear that the peripheral rural regions as well as structurally affected areas suffering from high unemployment have lower automoblization and public transport here has its social significance. This is mainly due to lower purchasing power of inhabitants that can influence spending on transport costs.

The scope of article does not allow to analyze all the related transport relationships. But it is clear that significance of different factors is different in different regions/localities and in different time. This will be a task for future analysis with help of geographically weighted regression (GWR). Above these objective factors we can see action of institutional factors that have a specific effect in particular on the supply of public transport. 
Table 2. Correlation relationships among selected indicators

\begin{tabular}{|c|c|c|c|c|c|c|c|c|}
\hline & 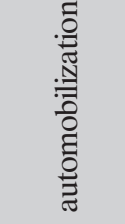 & 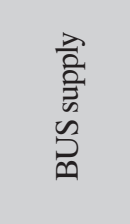 & 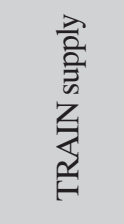 & 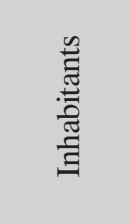 & 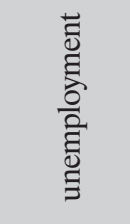 & 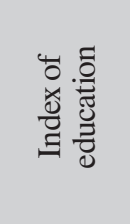 & $\begin{array}{l}\overline{0} \\
\frac{\vec{d}}{\pi} \\
\stackrel{\varpi}{n}\end{array}$ & 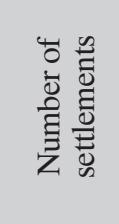 \\
\hline & 1 & 2 & 3 & 4 & 5 & 6 & 7 & 8 \\
\hline 1 & & $-.429(* *)$ & $-.506(* *)$ & $-.471(* *)$ & $-.641(* *)$ & $.261(* *)$ & $.182(*)$ & -0.021 \\
\hline 2 & $-.194(* *)$ & & $.659(* *)$ & $.808(* *)$ & $.212(* *)$ & $.411(* *)$ & $-.271(* *)$ & -0.102 \\
\hline 3 & $-.265(* *)$ & $.595(* *)$ & & $.818(* *)$ & $.309(* *)$ & $.188(*)$ & $-.309(* *)$ & 0.119 \\
\hline 4 & $-.090(* *)$ & $.651(* *)$ & $.527(* *)$ & & $.286(* *)$ & $.263(* *)$ & $-.241(* *)$ & 0.14 \\
\hline 5 & $-.410(* *)$ & $-.028\left(^{*}\right)$ & 0.01 & -0.002 & & $-.381(* *)$ & $-.266(* *)$ & -0.068 \\
\hline 6 & $.150(* *)$ & $.385(* *)$ & $.298(* *)$ & $.158(* *)$ & $-.336(* *)$ & & -0.049 & $-.241(* *)$ \\
\hline 7 & $.124(* *)$ & $-.174(* *)$ & $-.171(* *)$ & $-.053(* *)$ & $-.094(* *)$ & $-.096(* *)$ & & $.296(* *)$ \\
\hline 8 & $-.087(* *)$ & $.519(* *)$ & $.469(* *)$ & $.674(* *)$ & -0.024 & $.144(* *)$ & $.070(* *)$ & \\
\hline
\end{tabular}

Source: Census 2001 (CSO), Electronic time-table IDOS (CHAPS Brno), City and municipality statistics (CSO).

Notice: Pearson coefficients above diagonal are for micro-regions, below diagonal for municipalities Index of education $=3$ times share of inhabitants with university education + share of inhabitants with secondary education; Number of settlement=number of settlements within municipality. Other indicator see Table 1.

\section{DIFFERENTIATION OF TRANSPORT INDICATORS AND THEORY}

The indicator's differentiation presented could be framed by general theory of sociogeographic system development elaborated by Martin Hampl (2002, 1998, 2008 etc.; see also Novotný and Nosek 2009). The main statements of the theory could be summarised as follows:

1. Differentiation of sociogeographic systems according to their size and importance indicators has got hierarchical form. Units of the system necessarily need not have given subordination or super ordination, in this case "hierarchical" means especially size and importance polarisation in sense small—big, lagging—developed etc. and asymmetrical ("hierarchical") distribution of the set is typical: less maximums - a lot of minimums. This distribution repeats in reality and that's why it is regularity of complex systems' distribution.

2. Another repeating (regular) feature of sociogeographic systems is the similarity according to structural indicators of unites, i.e. urban population share, share of household equipped by car etc. These features are also called "speciesness" ones, because statistical distribution of sociogeographic system units converges to normal one, as in case of natural elementary systems unites (i.e. weight or height of individuals of one animal species). 
3. Finally, third geographical regularity is a diffusion process; it means gradual spreading of innovation/progressive changes in frames of whole system. Diffusion proceeds by neighbouring or hierarchically. In reality both types proceed together, of course, and whole mechanism leads to successive system re-homogenisation. However, at the beginning of the process, a new progressive change causes increase of system's hierarchization/polarization.

In the sense of the theory, transport hierarchy according to centres' size/importance indicators should follow hierarchical/asymmetric distribution. However, regularity of this distribution is effecting by centre's transport position in transportation network, by transportation policy influencing frequency of transport services, population size and regional importance of centre (=settlement hierarchy) etc. More selective character of railway network than road one is another factor "disturbing" regular distribution. In accordance with theoretical presumptions, among transport indicators used in this research the weighted number of public transport connections-as size/importance indicator-really tend to asymmetric distribution (Figure 4). And distribution of municipalities according to structural indicator (i.e. automobilization) has tendency to normal one.
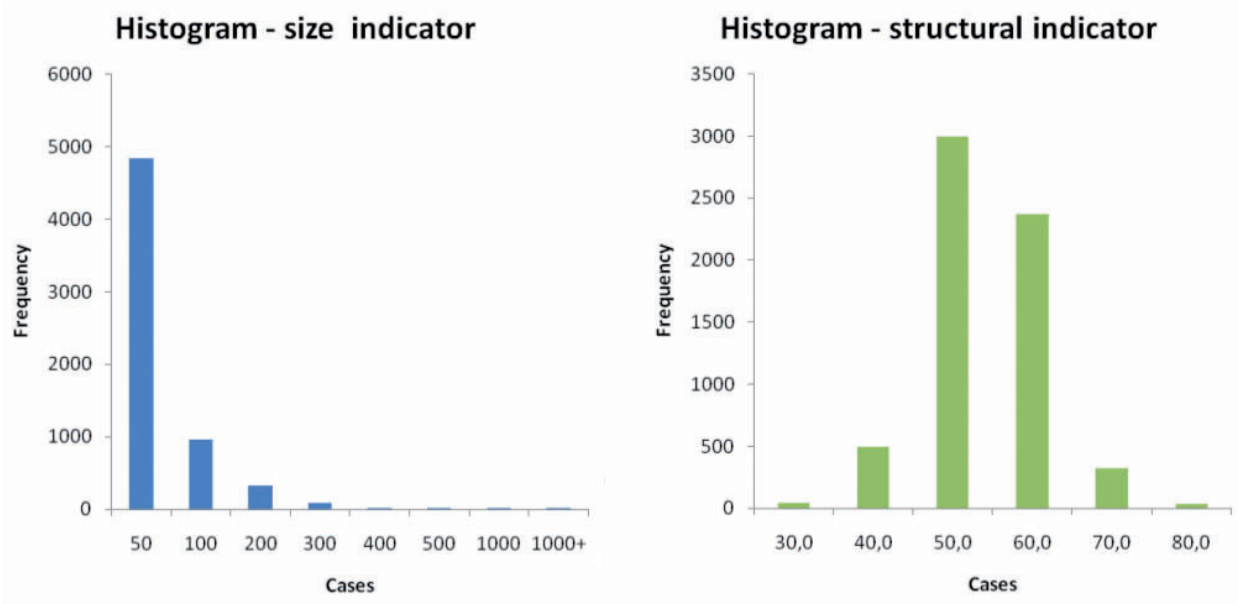

Figure 4. Statistical distribution of size/importance indicator and structural/qualitative one Source: electronic time-table IDOS 2008/2009, CSO (Census 2001).

Notice: Used indicators: number of departing public transport connections (left), share of municipality's households equipped by minimally one car (right).

\section{CONCLUSIONS}

Analysed transport indicators are of two fundamental types-size and structural ones. This fact causes that their differentiation will probably be developing in different way. While differentiation of settlement hierarchy, which is amount of public transport connections strongly dependent on, will increase, the share of households 
equipped by car(s) will tend to new optimum and re-homogenization of "normal type". Due to general differences in the settlement system in Bohemia and Moravia/ Silesia, small communities of Bohemia will always have a higher proportion of households with cars than larger municipalities in Moravia. In small villages, the people are increasingly reliant on individual motorization and the Bohemian regional authorities must prepare for a "more social" importance of the planned regional serviceability than in Moravian-Silesian regions with "larger" settlement.

Described differentiation will be modified by institutional and socio-cultural factors, i.e. transport policy in regional public transport service or individual modal choice. This influence will be probably increasing with decreasing size of settlements. Smaller centres and small settlements will be more reliant on the endowment policy of the state and self-administrative regions in the public transport and the extent of serviceability will be rather stable or declining. In the peripheral, sparsely populated areas, less favourable rail transport will be taken over by bus transportation. Especially in small settlement complementarity of the mass public and individual transport is noticeable. Important fact is that small municipalities are more dependent on individual transport and there is increased risk of "social exclusion" for certain segments of the population (e.g. children and adults-"non-drivers") in terms of inaccessibility. In this sense it is possible to formulate general recommendations for the organization of regional transport service: it should be noted that small municipalities/settlements in peripheral position are fully dependent on the subsidized public transport services and individual car transport and at that transport accessibility is considerable factor of local development, too.

\section{ACKNOWLEDGMENT}

This contribution was prepared thanks to the research project number KJB301110801 „Public and individual transport use for commuting to work and its geographical conditionality" supported by Grant Agency of Academy of Science and research project VaV WD-01-07-1 Regional differentiation of rural municipalities in Czechia: disparities a developmental possibilities supported by Ministry of local development of the Czech Republic. Authors are much obliged for kind support.

\section{REFERENCES}

Gray, D., Farrington, J. and Kagermeier, A. (2008), Geographies of rural transport,in: Knowles, R., Shaw, J., Docherty, I. (eds.) Transport geographies: mobilities, flows and spaces, Blackwell Publishing Ltd., Oxford, 102-119.

Hampl, M. (1998), Realita, společnost a geografická organizace: hledání integrálního rádu, Katedra sociální geografie a regionálního rozvoje, PřF UK, Praha. 
Hampl, M. (2002), Regionální organizace společnosti: principy a problémy studia, Geografie-Sborník ČGS, 107, 4, 333-348.

Hampl, M. (2004), Současný vývoj geografické organizace a změny v dojížd'ce za prací a do škol v Česku, Geografie-Sborník ČGS, 109, č. 3, ČGS, Praha, 205-222.

Hampl, M. (2005), Geografická organizace společnosti v České republice: Transformační procesy a jejich obecný kontext, Katedra sociální geografie a regionálního rozvoje, PřF UK, Praha, 148 s. + mapová př́loha.

Hampl, M. (2008), Nomotetická nebo idiografická geografie: alternativnost nebo komplementarita? Acta Geographica Universitatis Comenianae, 50, Prírodovedecká fakulta, Univerzita Komenského v Bratislavě, 19-31.

Hampl, M., Blažek, J. and Žížalová, P. (2008), Faktory—mechanizmy—procesy v regionálním vývoji: aplikace konceptu kritického realizmu, Ekonomický časopis, 56, (7), 696-711.

Hoyle, B. S. and Knowles, R. D. (eds.) (1998), Modern Transport Geography, Belhaven Press, London.

Hůrský, J. (1978), Regionalizace České socialistické republiky na základě spádu osobní dopravy, Studia Geographica, 59, Geografický ústav ČSAV, Brno, 182 s.

Knowles, R., Shaw, J. and Docherty, I. (eds.) (2008), Transport geographies: mobilities, flows and spaces, Blackwell Publishing Ltd., Oxford.

Květoň, V. (2006), Hodnocení dopravních možností obyvatel: analýza okresů Česka a mikroregionální pohled. Diplomová práce. katedra sociální geografie a regionálního rozvoje PřF UK, Praha, 103 s. + prríl.

Květoň, V. and Marada, M. (2008), Využití veřejné a individuální automobilové dopravyv Česku v dojižd'ce za pracía jeho geografická specifika, elektronický sborník ze sjezdu České geografické společnosti (Geografické dny Liberec),

Květoň, V., Marada, M., Chmelík, J. and Vondráčková, P. (2009), Vývoj dopravní obslužnosti veřejnou dopravou na př́kladu typově odlišných regionů, Acta Universitatis Carolinae, Univerzita Karlova v Praze, Př́rodovědecká fakulta, Praha, 16 s. rkp. (přijato do recenzního řízení).

Marada, M. et al. (2008), Doprava a geografická organizace společnosti v Česku, PřF UK, katedra sociální geografie a regionálního rozvoje, (rkp., v tisku).

Marada, M. and Hudeček, T. (2006), Accessibility of peripheral regions: a case of Czechia, EUROPA XXI-Regional periphery in central and eastern Europe, 15, Polish Academy of Sciences, Stanisław Leszczycki Institute of Geography and Spatial Organization, Warszawa, 43-49.

Marada, M. and Květoň, V. (2008), Importance of transport possibilities in rural areas of Czechia, conference proseedinga Countryside-our World, ČZU, Praha, 390-406.

Moseley, J., M., Harman, G., R., Coles, B. and O., Spencer. B.M. (1977), Rural transport and Accessibility, Centre of East Anglian Studies, University of East Anglia, Norwich.

Novotný, J. and Nosek, V. (2009), Nomothetic geography revisited: Statistical distri- 
butions, their underlying principles and inequality measures, Geografie-Sborník $\check{C} G S, 114$, č. 16, Praha, 282-297 (in print).

Nutley, S. (1998), Rural areas: accessebility problem, in: Hoyle, B. and Knowles, R. (eds.) Modern transport geography, 2nd rev. edition, Wiley and sons, Chichester, $185-215$.

Rietveld, P. and Vickerman, R. W. (2004), Transport in regional science: the „Death of Distance“ is premature, Papers in Regional Science, 83, č. 1, RSAI, Leeds, 229-248.

Seidenglanz, D. (2007), Dopravní charakteristiky venkovského prostoru, Disertační práce, Masarykova Univerzita v Brně, 171 s. + př́lohy.

Urry, J. (1999), Automobility, car culture and weightless travel: a discussion paper. Department of Sociology, Lancaster University, Lancaster, <http://www.comp. lancs.ac.uk/sociology/papers/Urry-Mobile-Cultures.pdf > 